\title{
Geovisual Analytics of Spatio-Temporal Earthquake Data in Indonesia
}

\author{
Febrian Fitryanik Susanta ${ }^{1}$, Cecep Pratama ${ }^{1}$, Trias Aditya ${ }^{1}$, Alian Fathira Khomaini' ${ }^{2}$, Hadi Wijaya Kusuma Abdillah ${ }^{3}$ \\ 1 Departemen Teknik Geodesi, Fakultas Teknik, Universitas Gadjah Mada, Yogyakarta, Indonesia \\ 2 Mahasiswa Departemen Teknik Geodesi, Fakultas Teknik, Universitas Gadjah Mada, Yogyakarta, Indonesia \\ ${ }^{3}$ Alumni Program Studi Sarjana Departemen Teknik Geodesi, Fakultas Teknik, Universitas Gadjah Mada, Yogyakarta, Indonesia
}

\section{Article History:}

Received 3 November 2019

Received in revised form 14 December 2019

Accepted 19 December 2019

Available online 30 December 2019

\section{Keywords:}

Dashboard, geovisualization, spatiotemporal analysis, disaster

Corresponding Author:

Febrian Fitryanik Susanta

Email: febrian.fitryanik.s@ugm.ac.id

\begin{abstract}
Indonesia is one of the nations located in the Ring of Fire. High geodynamic occurrences cause often occurring earthquake tectonics in Indonesia. The earthquakes are also caused by Indonesia position which is in the confluence of four main plates. Earthquake data in Indonesia has been accessible by the public. However, the map and graphical of historical earthquake data have not been available. This research aims to create a visualization dashboard of historical earthquake combining spatial and temporal data. The data used for this research was obtained from BMKG website. The data contain CORS stations and historical earthquake data in 2004 to 2019. In addition, seismic data attributes such as earthquake magnitude and depth. The data are processed using Ms Excel and ArcGIS Online Map then WebAppBuilder for ArcGIS is used to build a visualization dashboard. We have designed and implemented a visualization dashboard, VizEQ, which present a map, time-series animation and graphical widgets of historical earthquake data. Dashboard interfaces support visual analytics method to create the relationship between variables. In this paper, we present the visual analytics techniques to build visual queries as users explore the data.
\end{abstract}

(C) Author(s) 2019. This is an open access article under the Creative Commons Attribution-ShareAlike 4.0 International License (CC BY-SA 4.0).

\section{Pendahuluan}

Indonesia menjadi salah satu negara dengan frekuensi aktivitas gempa bumi yang tinggi. Ini dikarenakan aktvitas geodinamika yang terjadi di Indonesia. Kondisi ini disebabkan oleh zona subduksi yang berada di selatan Pulau Jawa, yang terbentuk melalui aktivitas Lempeng Indo-Australia terhadap paparan Blok Sunda. Lempeng Indo-Australia membentang dari Benua Australia hingga India, yang sebagian dari lempeng tersebut menunjam di bawah Pulau Jawa dan Sumatera yang menjadi batas paling selatan dari paparan Blok Sunda (Bock, 2003). Didukung dengan kondisi Indonesia yang memiliki jumlah kepadatan penduduk yang tinggi, menyebabkan dampak risiko gempa bumi semakin tinggi.

Gempa bumi merupakan salah satu jenis bencana yang tidak dapat diprediksi secara pasti, dihindari maupun dicegah kapan terjadinya (Pusat Studi Gempa Nasional, 2017). Tak jarang, gempa bumi selalu diikuti dengan bencana tsunami yang dapat menimbulkan banyak kerugian, baik kerugian materiil maupun korban jiwa.
Oleh karena itu, perlu adanya suatu tindakan preventif sebagai upaya tanggap darurat dan mitigasi bencana gempa bumi.

Saat ini, BMKG telah menyediakan repository gempa bumi yang dapat diakses secara gratis oleh publik melalui halaman website http://repogempa.bmkg.go.id/. BMKG berharap dapat menyediakan dan melayani informasi gempa bumi yang cepat dan akurat. Namun, data yang tersedia hanya dapat diakses dalam format *.csv sehingga pengguna belum dapat melihat persebaran terjadinya gempa bumi di Indonesia. Di samping itu, pengguna juga belum bisa melakukan analisis dari data yang disajikan. Untuk masyarakat awam, persebaran terjadinya gempa bumi, waktu terjadinya, statistik informasi gempa dapat menjadi penting untuk diketahui. Namun pengguna tidak perlu untuk melakukan unduh data, pengolahan data, dan penyajian data. Oleh karena itu, penelitian ini bertujuan untuk memvisualisasikan histori terjadinya gempa bumi di Indonesia secara spasio temporal, dalam tampilan dashboard yang bersifat visual interaktif dan mengizinkan 
pengguna untuk membuat kueri visual saat mereka mengeksplorasi data.

Penyajian histori terjadinya gempa bumi ini memegang peranan penting dalam menyampaikan informasi ke pengguna untuk mendapatkan tanggapan dan pengambilan keputusan. Hasil visualisasi yang baik akan mendukung pemahaman oleh pengguna. Sedangkan kesalahan pemilihan visulisasi akan membuat hasil visualisasi menjadi tidak tersampaikan secara efektif. Analitis visual adalah salah satu metode visualisasi yang digunakan dalam penelitian ini. Analitis visual merupakan hasil kombinasi dari kekuatan pengolahan data antara manusia dan komputasi (Andrienko dkk., 2010). Analitis visual menggabungkan teknik analisis secara otomatis dengan visualisasi interaktif untuk pemahaman yang efektif, penalaran dan pengambilan keputusan pada tingkat dasar yang digunakan pada data yang besar dan kompleks (Keim dkk., 2008).

Data histori terjadinya gempa bumi ini terdiri dari data spasial, data non spasial dan data waktu. Visualisasi dengan metode analitis visual dari data spatio temporal yang interaktif ini menjadi perlu untuk dilakukan karena kemudahan dalam memahami hubungan antar datanya. Penyajian histori terjadinya gempa bumi yang interaktif ini akan menjadi sebuah platform yang efektif dan efisien untuk dasar pengambilan keputusan dan sebagai sarana untuk mengedukasi masyarakat sehingga risiko bencana gempa bumi dapat diminimalisir.

\section{Penelitian Sebelumnya}

Aktivitas gempa bumi disebabkan oleh zona subduksi yang berada di selatan Pulau Jawa, yang terbentuk melalui aktivitas Lempeng Indo-Australia terhadap paparan Blok Sunda. Lempeng Indo-Australia memiliki besar pergerakan $68 \mathrm{~mm}$ per tahun dengan arah pergerakan menuju timur laut (Meilano dkk., 2012) sedangkan Blok Sunda yang menjadi blok terbesar yang ada di kepulauan Indonesia (Bock, 2003) memiliki besar pergerakan $6 \mathrm{~mm}$ s.d. $10 \mathrm{~mm}$ relatif terhadap Lempeng Eurasia dengan arah pergerakan menuju tenggara (Simons dkk., 2007). Zona subduksi terbentuk melalui proses pertumbukan antara kedua lempeng yaitu lempeng Eurasia dan Indo-Australia (Hamilton, 1979) sehingga terbentuk pola geologi regional berupa penunjaman, patahan maupun sesar aktif yang merupakan salah satu zona sumber gempa bumi (Pusat Studi Gempa Nasional, 2017).

Analitis visual dapat menampilkan hubungan antar data yang beragam dengan sangat baik. Oleh karena itu, pendekatan analitis visual dapat digunakan untuk eksplorasi dan analisis data yang memiki informasi temporal atau bersifat dinamis (Elzen dkk., 2016). Metode visual analitik dapat memfasilitasi untuk eksplorasi kumpulan data spasial dan temporal, yang mengkombinasikan tampilan dan pemilihan secara interaktif untuk memberikan informasi tentang data dan memungkinkan pengguna mengembangkan dan mengeksplorasi hipotesis mereka (Maciejewski dkk, 2009).

Hernández-Castro and Monge-Fallas (2019) melakukan eksplorasi dan analisis data gempa bumi dan menampilkan dalam sebuah system. Hernández-Castro and Monge-Fallas (2019) membuat desain dan mengimplementasikan sebuah perangkat visualisasi, Plinius, yang digunakan untuk menganalisis lokasi kejadian gempa dalam model 3D dari data tahun 1984 s.d. 2016. Plinius dapat menampilkan konvergensi dari lempeng tektonik yang berbeda di Costa Rica, mendeteksi kegiatan seismis yang baru terjadi, dan menyediakan manajemen data yang dibutuhkan mengenai batas administrasi wilayah. Data gempa bumi ditampilkan dalam visualisasi 3D dilengkapi dengan system navigasi sesuai kebutuhan pengguna dan disajikan dalam tiga tampilan dashboard yaitu dashboard hiposenter, dashboard geografis dan dashboard data secara general.

Visualisasi potensi gempa bumi di Indonesia menggunakan metode penyajian analitis visual dapat menjadi salah satu inovasi yang baik untuk memahami deformasi dan peta potensi bahaya gempa di Indonesia. Dalam penelitian Dharmawan dkk. (2017), data gempa bumi tahun 2010 sampai tahun 2015 digeovisualisasikan dengan menggunakan metode hexagonal tessellation. Hasilnya menunjukkan bahwa dengan metode tersebut, peta gempa bumi di Indonesia dapat menunjukkan distribusi kepadatan dari titik lokasi kejadian gempa bumi secara spasio temporal. Peta disajikan dalam bentuk peta cetak dengan dilengkapi informasi tambahan berupa besaran magnitude.

Histori gempa ini menjadi penting sebab sebagai salah satu pertimbangan bahwa daerah yang pernah terdampak akan memiliki potensi terulang baik secara stokastik maupun statistik (Pusat Studi Gempa nasional, 2017). Oleh karena itu, dalam penelitian ini, histori gempa bumi disajikan dengan metode hexagonal tessellation namun dikombinasikan dengan tampilan dashboard sehingga dapat bersifat secara interaktif. Dengan memvisualisasikan pola dan kecerendungan dari kejadian gempa, maka pemodelan peta potensi bahaya gempa yang dapat menjawab pernyataan pengguna dapat terealisasi sehingga mendukung tujuan mitigasi bencana yang ada di Indonesia.

\section{Data dan Metodologi}

\subsection{Data dan Lokasi}

Data yang digunakan untuk penelitian ini adalah data histori terjadinya gempa bumi tahun 2004 sampai dengan tahun 2019 di Indonesia yang bersumber dari data BMKG serta data stasiun CORS yang tersebar di seluruh Indonesia beserta koordinatnya. Data histori gempa diunduh secara gratis melalui halaman website http://repogempa.bmkg.go.id/repo_new/repository.php dalam format teks (*.csv). Sedangkan data stasiun CORS diperoleh dari halaman website http://srgi.big.go.id/srg. Data yang diperoleh terdiri dari data waktu terjadinya gempa, posisi pusat terjadinya gempa, pusat kedalaman gempa, dan besar magnitude gempa.

Lokasi yang digunakan untuk penelitian ini meliputi seluruh wilayah Indonesia. Tepatnya terletak pada koordinat $6^{\circ}$ Lintang Utara s.d. $11^{\circ}$ Lintang Selatan dan $94^{\circ}$ Bujur Timur s.d. $141^{\circ}$ Bujur Timur. 


\subsection{Metodologi}

Secara umum, tahapan pelaksanaan penelitian ini dibagi menjadi empat tahapan yaitu tahap persiapan, pengolahan data, desain analitis data spatio temporal, analitik geovisual dalam tampilan dashboard dan pengujian tampilan.

Tahap persiapan meliputi pengumpulan data dan studi literatur. Tahapan pengolahan data dilakukan dengan perangkat lunak Microsoft Excel dan menggunakan ArcGIS Online WebMap untuk pengaturan tampilan peta dan style-nya. Tahapan desain analitis data spatio temporal meliputi identifikasi data yang akan divisualisasikan, melakukan analisis tambahan yang diperlukan, mendesain tamiplan analisis visual dan kebutuhan sistem. Kemudian tahapan terakhir dilanjutkan dengan memvisualisasikan hasil desain ke dalam tampilan dashboard dan pengujian untuk memastikan dashboard berjalan dengan baik. Untuk tahapan implementasi penelitian ini disajikan dalam Gambar 2.1.

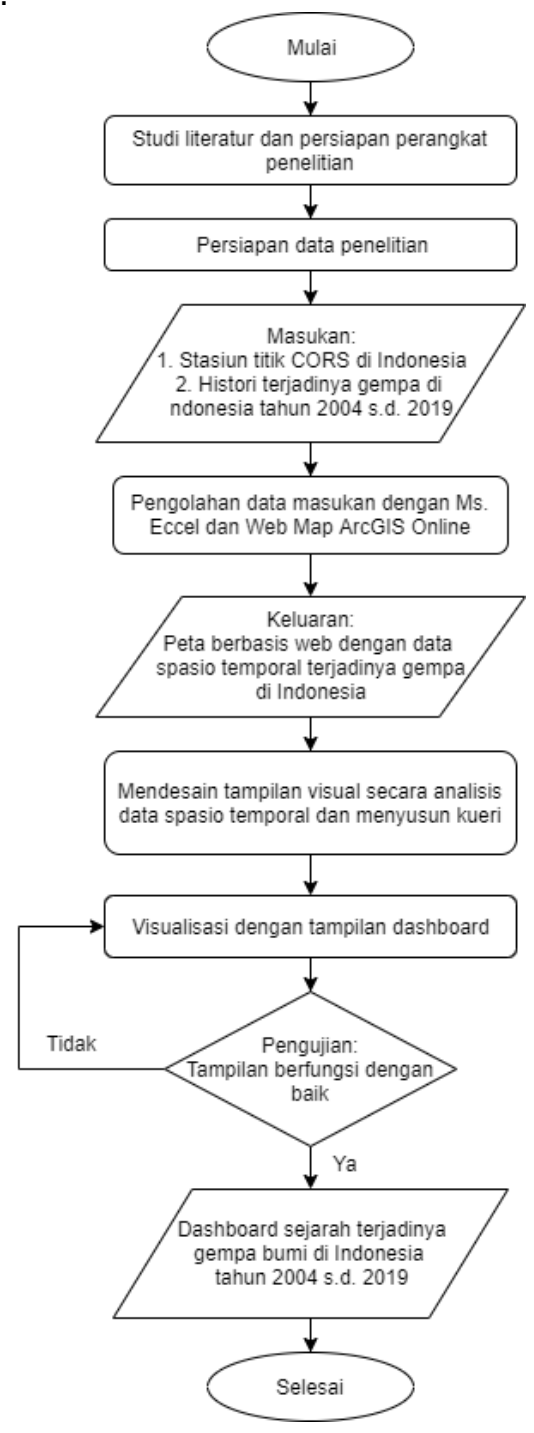

Gambar 2.1 Tahapan implementasi penelitian

\section{Pengolahan data}

Pengolahan data yang dilakukan meliputi data statistik, data temporal dan data spasial. Pengolahan data spasial dikerjakan menggunakan ArcGIS Online Web Map sedangkan pengolahan data statistik dan temporal dikerjakan menggunakan Microsoft Excel untuk mengatur format angka dan waktu sesuai standar format yang telah ditetapkan oleh ESRI untuk ArcGIS.

Data statistik dilakukan untuk melakukan klasifikasi kedalaman pusat gempa dan besar kekuatan gempa. Untuk kedalaman $0 \mathrm{~km}$ s.d. $30 \mathrm{~km}$ digolongkan sebagai shallow earthquake, kedalaman $30 \mathrm{~km}$ s.d. $100 \mathrm{~km}$ digolongkan sebagai gempa dalam/intermediate intraslab earthquake, dan kedalaman $100 \mathrm{~km}$ s.d. $300 \mathrm{~km}$ sebagai gempa sangat dalam / deep intraslab earthquake. Besar kekuatan gempa digolongkan menjadi 4 kelas, kelas pertama gempa dengan kekuatan di bawah 5,9 Mw disebut gempa kecil. Gempa dengan kekuatan $6 \mathrm{Mw}$ s.d. 6,9 Mw disebut gempa menengah. Gempa dengan kekuatan $7 \mathrm{Mw}$ s.d. 8,9 Mw disebut gempa besar (large earthquake) dan gempa dengan kekuatan di atas $9 \mathrm{Mw}$ disebut gempa megathrust (Megathrust Earthquake). Untuk format angka ditentukan berdasarkan format ESRI yaitu MM/DD/YYYY hh:mm. Hal ini diperlukan agar data waktu dikenali oleh ArcGIS untuk menyusun time series animation di ArcGIS.

Pengaturan style/tampilan untuk memilih simbol, warna, dan jenis klasifikasi yang digunakan. Style yang digunakan yaitu unique symbol untuk klasifikasi data kedalaman dan besar kekuatan, single symbol untuk stasiun titik CORS, dan heatmap untuk klasifikasi frekuensi jumlah kejadian gempa (Metsalu dan Vilo, 2015). Sedangkan untuk waktu terjadinya gempa dilakukan pengaturan menggunakan time series animation (Heer dkk., 2008). Interval waktu yang ditampilkan yaitu tiap satu bulan selama 15 tahun.

Sebagai tambahan analisis frekuensi terjadinya gempa, dibuat menggunakan analisis hexagon polygon dan mengatur style untuk memilih warna yang sesuai dengan tema (Dharmawan dkk, 2017). Terakhir pada tahapan ini adalah melakukan evaluasi tampilan untuk pengujian dan mengkoreksi hal-hal yang memerlukan perbaikan.

\section{Mendesain Tampilan Analisis Data Spatio Temporal}

Mendesain tampilan dimulai dari desain halaman web meliputi tampilan dashboard baik tampilan widgets maupun tampilan peta, mendefinisikan interaksi pengguna untuk mendukung fungsi analisis secara visual, dan merumuskan kerangka kerja web yang akan digunakan.

Dalam penelitian (Von Landesberger dkk., 2012) menyajikan pendekatan baru dari metode analitis visual yaitu mengkombinasikan (1) visualiasi data kategori yang berubah terhadap waktu (2) beberapa tampilan data spasial (3) teknik komputasional untuk pemilihan beorientasi kueri dari time series. Dengan metode analitis visual, dapat disajikan perubahan visualisasi secara ekspresif yang menyeluruh dari waktu ke waktu. Dengan pendekatan baru ini, diharapkan semua kejadian dapat terdeteksi dan wawasan baru dapat diperoleh.

Penyajian tampilan ini menggunakan kerangka Web AppBuilder for ArcGIS. Sedangkan, tampilan untuk mendukung analisis yang dapat ditampilkan sebagai widgets meliputi klasifikasi besar kekuatan gempa, 
klasifikasi kedalaman, banyaknya kejadian gempa per tahun dan per lokasi wilayah sesuai dengan tampilan peta.

Peta ditampilkan dalam bentuk layer groups dan layer controls. Sedangkan untuk data statistik lainnya ditampilkan dengan grafik. Grafik yang digunakan dalam penelitian ini adalah grafik garis dan grafik lingkaran, penyajian nilai indikator dan legenda dari masing-masing daftar atribut. Sedangkan untuk informasi waktu, perlu diaktifkan widgets time series animation.

\section{Analitis Geovisual dalam tampilan Dashboard}

Analitis visual memfasilitasi adanya penghubung antara persepsi manusia dengan teknologi komputasi. Naluri manusia dan kecepatan interaksi pemikiran dapat diperoleh melalui perangkat visualisasi yang bersifat dinamis dan interaktif. Ditambah dengan layar yang maksimum untuk tampilan visual membantu pengguna tetap fokus pada pekerjaan dan mempersingkat waktu untuk memperoleh pemahaman baru (Jern dan Franzen, 2006).

Visualisasi tampilan dashboard agar menghasilkan tampilan visual yang bersifat analisis (analitis visual). Keseluruhan tampilan dibuat interaktif sehingga pengguna dapat memilih dan merubah tampilan. Untuk mendukung analisis dari data spatio temporal, metode clustering dan teknik interaktif dapat diterapkan untuk mengelompokkan waktu kejadian. Metode statistik untuk pemodelan time series kemudian diaplikasikan untuk mempresentasikan kejadian dari time series yang serupa. Hasil penyajian ini dapat bermanfaat untuk berkomunikasi dengan pengguna dan dapat digunakan sebagai dasar untuk memprediksi kejadian serta analisis komputasional lainnya. Dari perspektif analitis visual, hasil penyajian ini dapat memunculkan pola spatio-temporal dalam pikiran analisis sebagai hasil analisis visual interaktif (Andrienko dan Andrienko, 2013).

\section{Pengujian tampilan Dashboard}

Tampilan analitis visual yang dihasilkan sebaiknya userfriendly dan mudah dipahami oleh pengguna (Popelka, 2019). Oleh karena itu, penyajian tampilan perlu dievaluasi baik dari segi tampilan, segi fungsionalitas maupun kueri yang dapat diselesaikan oleh pengguna. Harapannya analisis yang disajikan ini dapat membantu pengambilan keputusan dalam tingkat paling sederhana Bila masih mengandung kesalahan, maka dilakukan perbaikan tampilan berdasarkan evaluasi sebelumnya.

\section{Hasil dan Pembahasan}

Hasil dari penelitian ini adalah berupa tampilan dashboard yang menampilkan analisis pola terjadinya gempa di Indonesia baik secara spasial maupun temporal. Hasil visualisasi ini terdiri dari tiga tampilan utama yaitu tampilan dalam bentuk peta, grafik, dan tampilan time series animation. Keseluruhan tampilan bersifat interaktif sehingga pengguna dapat memberikan queri yang akan secara dinamis merubah tampilan dashboard. Dari hal ini diharapkan pengguna mendapatkan wawasan baru yang merupakan tujuan dari penyajian data menggunakan metode analitis visual.

\subsection{Hasil Visualisasi Dashboard}

Dashboard menyajikan data spasial dan analisisnya yang divisualisasikan dalam bentuk peta. Data spasial ini terdiri dari persebaran titik stasiun CORS di Indonesia dan persebaran kejadian gempa, sedangkan analisis frekuensi titk terjadinya gempa ditampilkan dalam bentuk heatmap dan hexagon polygon dimana warna yang semakin gelap menunjukkan intensitas yang tinggi. Untuk data statistik seperti nilai kedalaman dan besar kekuatan gempa berdasarkan jumlah gempa per tahun ditampilkan dalam bentuk grafik lingkaran dan grafik garis. Sedangkan, data temporal waktu terjadinya gempa ditampilkan dalam bentuk time-series animation. Tampilan peta dilengkapi dengan pop-up, skala, legenda, visibilitas layer, pilihan basemap, pencarian lokasi, perbesaran tampilan dan informasi dashboard. Tampilan dashboard untuk lebih lengkapnya dapat dilihat pada Gambar 3.1.

Target pengguna dari visualiasasi dashboard ini adalah masyarakat awam. Manfaat bagi masyarakat awam adalah memudahkan mereka untuk mengetahui persebaran terjadinya gempa bumi di Indonesia sehingga dapat digunakan sebagai pendukung pengambilan keputusan dalam manajemen mitigasi bencana tingkat paling sederhana. Di samping itu, sebagai sarana untuk mengedukasi masyarakat yang memungkinkan untuk meminimalisir risiko terjadinya gempa bumi di Indonesia.

Dashboard bersifat dinamis dan interaktif sehingga pengguna dapat memberikan kueri sesuai kebutuhan. Kueri dapat diberikan sesuai skenario yang akan diterapkan pada kondisi nyata nantinya. Analitis visual mengkombinasikan kekuatan dari pengolahan data dari pengguna dan proses komputer dimana keduanya bekerja bersama untuk memudahkan pengguna mendapatkan wawasan dan pemahaman baru.

Tampilan dashboard menggunakan tema warna gelap, sehingga pengguna dapat langsung fokus pada informasi yang divisualisasikan. Sedangkan untuk pemilihan warna pada widgets yang ditampilkan menggunakan warna yang konsisten dan seragam. Ini untuk menekankan bahwa keseluruhan data masih terhubung satu sama lain. Dalam penelitian ini, variabel visual digunakan untuk mendeskripsikan keberagaman data yang ditunjukkan dengan perbedaan warna dan bentuk untuk data kuantitatif dan perbedaan nilai untuk data kualitatif. Peta dasar untuk tampilan peta menggunakan basemap dari Dark Gray Canvas. Tampilan dari masing-masing layer dapat dilihat pada Gambar 3.2, Gambar 3.3, Gambar 3.4 dan Gambar 3.5.

Apabila pengguna memilih fitur pada web map tersebut, maka akan muncul pop-up. Untuk fitur stasiun titik CORS, atribut yang ditampilkan meliputi nama stasiun CORS dan koordinat lokasinya. Sedangkan untuk fitur titik terjadinya gempa, yang ditampilkan semua informasi atribut meliputi waktu terjadinya gempa, lokasi koordinat dalam lintang dan bujur, alamat lokasi gempa dalam deskripsi, kedalaman pusat gempa dalam $\mathrm{km}$, besar kekuatan gempa dalam Mw, serta nilai Moment seismic nya 


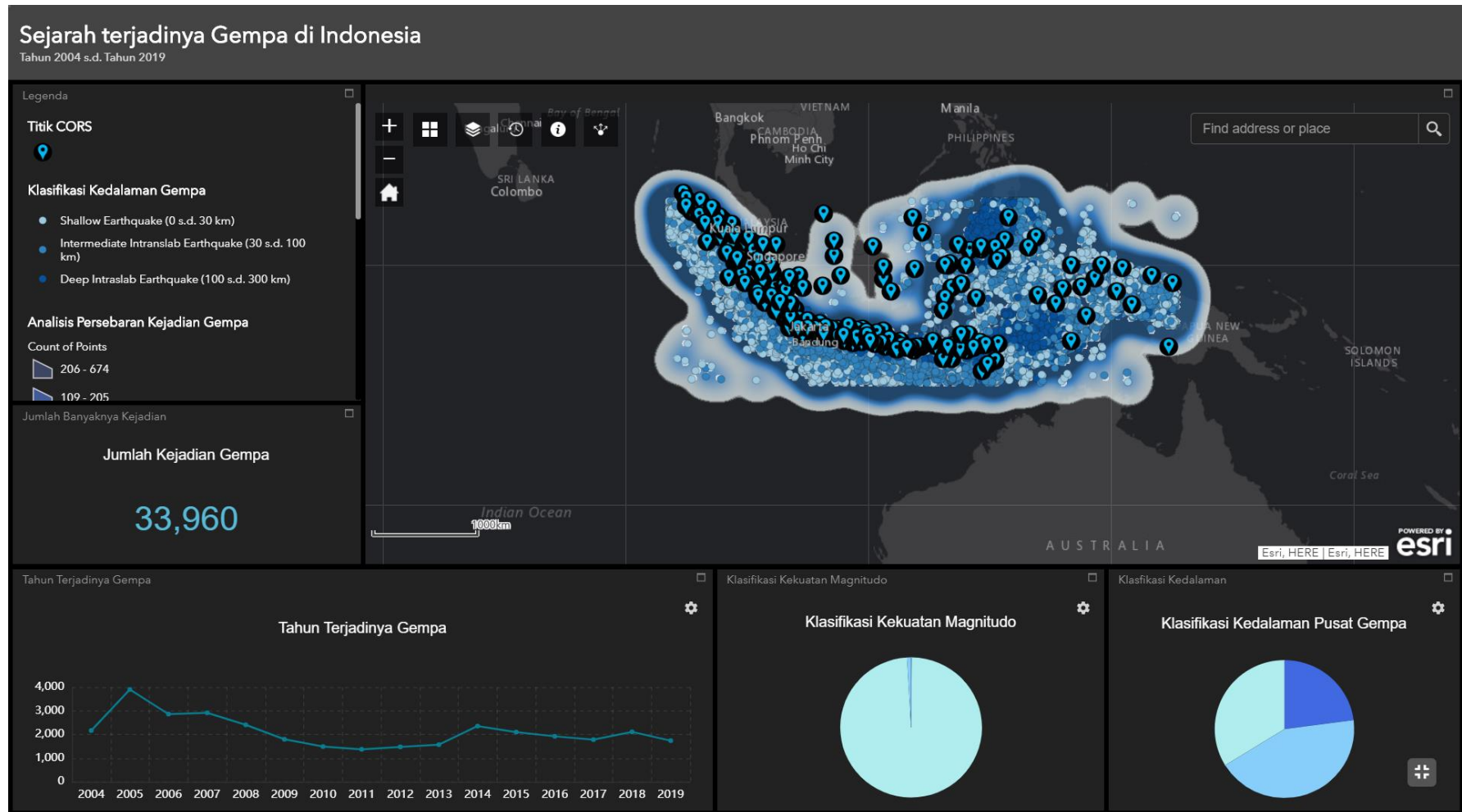

Gambar 3.1 Tampilan dashboard sejarah terjadinya gempa di Indonesia mulai tahun 2004 sampai dengan 2019

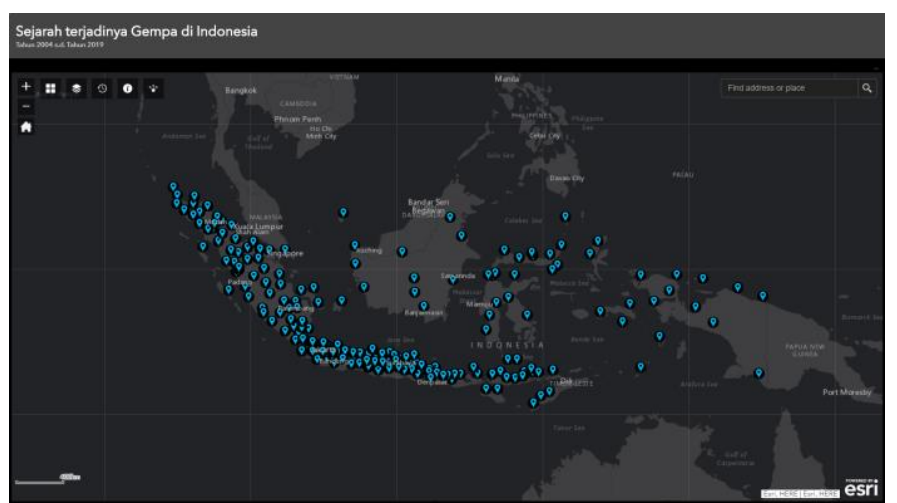

Gambar 3.2 Tampilan persebaran stasiun titik CORS di Indonesia

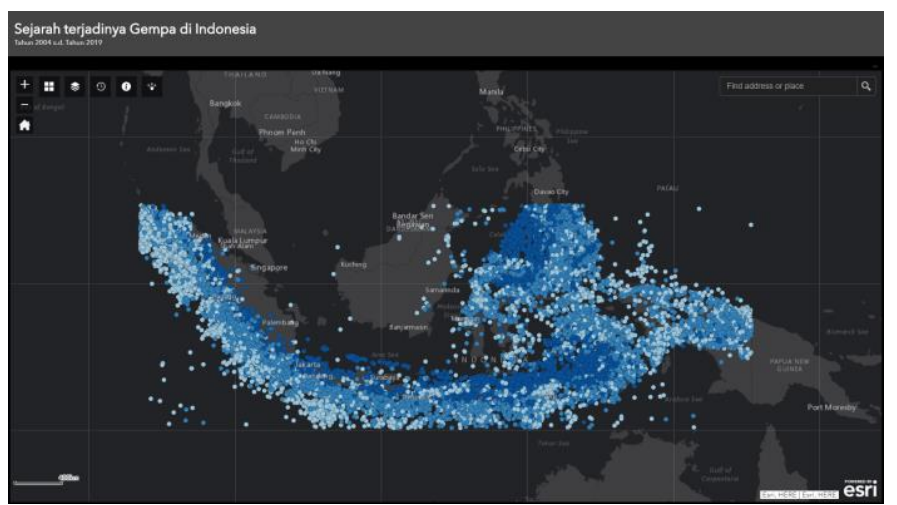

Gambar 3.3 Tampilan klasifikasi kedalaman pusat gempa di Indonesia

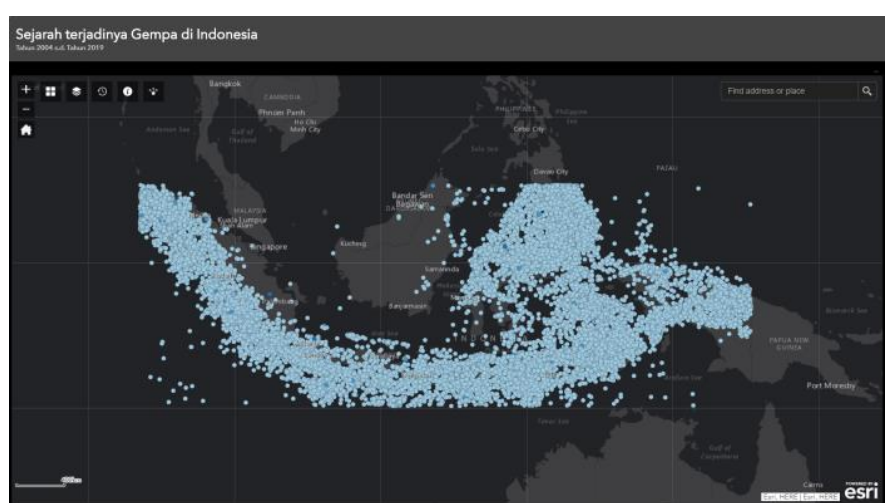

Gambar 3.4 Tampilan klasifikasi besar kekuatan gempa di Indonesia

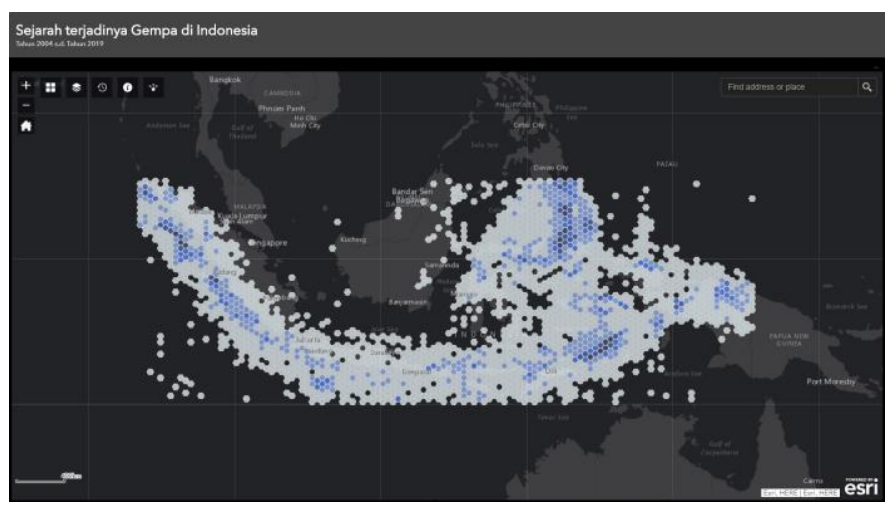

Gambar 3.5 Tampilan analisis persebaran kejadian gempa berdasarkan frekuensi terjadinya 


\subsection{Analisis Spatio Temporal}

Penelitian ini menyajikan data kejadian gempa bumi di Indonesia yang terdiri data spasial dan temporal menggunakan metode geovisualisasi. Visualisasi menggunakan metode analitis visual yang memfasilitasi pengguna untuk berfikir secara visual. Pengguna dapat mengeksplor tampilan peta dan grafik yang disajikan. Pengguna diharapkan dapat memahami pola dan hubungan dari data yang ditampilkan. Oleh karena itu, interaksi pengguna sangat tinggi dalam menggunakan dashboard ini. Manfaat dari metode ini adalah dapat mendukung analisis data spasial, non spasial dan temporal secara visual interaktif sehingga mendorong pengguna untuk mendapatkan pengetahuan dan wawasan baru dari data yang ditampilkan sehingga menumbuhkan pemahaman serta mendukung pengambilan keputusan berbasis spasial. Beberapa kueri yang bisa dilakukan oleh pengguna melalui dashboard ini diantaranya adalah sebagai berikut.

1. Pengguna dapat fokus pada satu wilayah area tertentu dengan mengatur extent pada peta untuk menganalisis pola terjadinya gempa di daerah tertentu saja. Hasilnya ditunjukkan pada Gambar 3.6.

2. Pengguna dapat melihat tingkat frekuensi daerah persebaran kejadian gempa dengan interval satu bulan dari segi kedalaman pusat gempa. Hasilnya ditunjukkan pada Gambar 3.7.

3. Pengguna dapat melihat tingkat frekuensi daerah persebaran kejadian gempa dengan interval satu bulan dari segi besar kekuatan gempa. Hasilnya ditunjukkan pada Gambar 3.8.

4. Pengguna dapat melihat analisis persebaran kejadian gempa berdasarkan frekuensi terjadinya dari area tertentu yang diinginkan. Hasilnya ditunjukkan pada Gambar 3.9.

Sedangkan untuk contoh masing - masing kueri di atas, apabila ingin mengetahui jumlah masing - masing klasifikasi kekuatan, klasifikasi kedalaman dan jumlah per tahunnya, dapat dilihat secara langsung dengan mengarahkan mouse ke grafiknya. Contoh dapat dilihat pada Gambar 3.10 untuk grafik kedalaman pusat gempa, Gambar 3.11 untuk grafik besar kekuatan gempa, dan Gambar 3.12 untuk grafik kejadian gempa tiap tahunnya.

\subsection{Diskusi}

Dari hasil yang ditemukan dalam penelitian ini, telah dikonfirmasi bahwa pengguna dapat melihat pola kejadian gempa di seluruh wilayah di Indonesia, baik dari segi lokasi kejadian, kedalaman pusat gempa dan besar kekuatan gempa. Dari hasil penelitian, dapat ditunjukkan pula lokasi persebaran dari stasiun pengamatan titik CORS di Indonesia.

Namun, hasil menarik dari penelitian ini adalah jumlah kejadian gempa yang relatif menurun dari tahun 2004 sampai dengan 2019. Besar kekuatan gempa yang cenderung kecil yaitu di bawah 5.9 Mw. Serta kejadian gempa yang tinggi terjadi di bagian selatan Pulau Sumatera, Laut Banda, dan bagian utara Sulawesi. Selain itu, besar kedalaman gempa cenderung lebih tinggi di bagian utara daripada di bagian selatan. Hal tersebut dapat terjawab dengan menambahkan data seperti kecepatan gerakan deformasi di masing-masing stasiun CORS, lokasi patahan di Indonesia, besaran magnitude seismik serta jarak horizontal gempa masih bisa dirasakan. Dengan demikian, dapat mendukung kegiatan manajemen mitigasi bencana di Indonesia.

Penambahan variabel tentunya akan menambah analisis yang dapat disajikan secara kueri visual. Oleh karena itu, akan memunculkan tantangan bagaimana menampilkan data yang kompleks dan beragam dalam sebuah tampilan dashboard baik dari segi tampilan, fungsionalitas perangkat tampilan, pemilihan grafik, peta maupun style yang dapat memudahkan pengguna untuk memahami data yang ditampilkan. Pengujian tampilan dashboard memegang peranan penting mulai dari perencanaan sampai dashboard akan disajikan kepada pengguna. Tampilan dashboard harus mudah diakses oleh semua orang, mudah digunakan, akurat dan keamanan tetap terjamin bagi semua pihak (Ismailova, 2017).

\section{Kesimpulan}

Berdasarkan pada penelitian yang telah dilakukan, hasil akhir dari penelitian ini adalah dashboard visualisasi kejadian gempa bumi di Indonesia mulai tahun 2004 sampai dengan tahun 2019 dari data spasial dan temporal. Data spasial ini terdiri dari persebaran titik stasiun CORS di Indonesia dan persebaran kejadian gempa, sedangkan analisis frekuensi titk terjadinya gempa ditampilkan dalam bentuk heatmap dan hexagon polygon. Untuk data statistik seperti nilai kedalaman dan besar kekuatan gempa berdasarkan jumlah gempa per tahun ditampilkan dalam bentuk grafik lingkaran dan grafik garis. Sedangkan, data temporal waktu terjadinya gempa ditampilkan dalam bentuk time-series animation. Tampilan peta dilengkapi dengan pop-up, skala, legenda, visibilitas layer, pilihan basemap, pencarian lokasi, dan perbesaran tampilan. Keseluruhan tampilan ini bersifat interaktif sehingga memungkinkan tampilannya berubah dinamis sesuai dengan queri yang diberikan oleh pengguna. Hal ini mendukung fungsi analitis visual yang dapat memberikan wawasan baru bagi pengguna. Dashboard ini membuat pengambil kebijakan mudah untuk memonitor dan mengevaluasi persebaran stasiun CORS dan titik terjadinya gempa untuk mendukung penataan dan pengembangan jaringan stasiun CORS. Di samping itu, hasil penelitian ini diharapkan dapat memberi masukan untuk meningkatkan kualitas manajemen mitigasi bencana di Indonesia. 


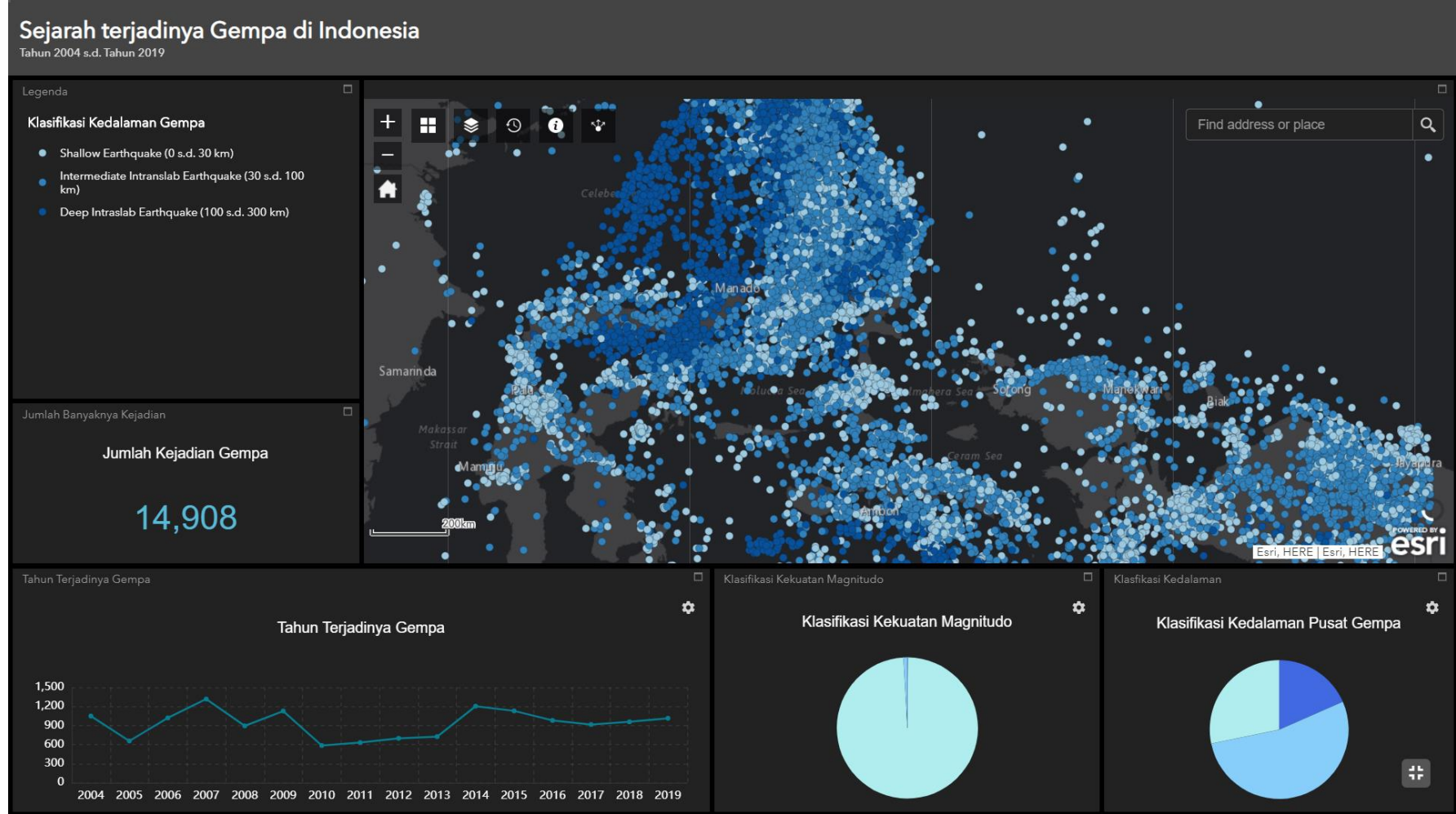

Gambar 3.6 Tampilan dashboard pada kueri pertama dari pengguna

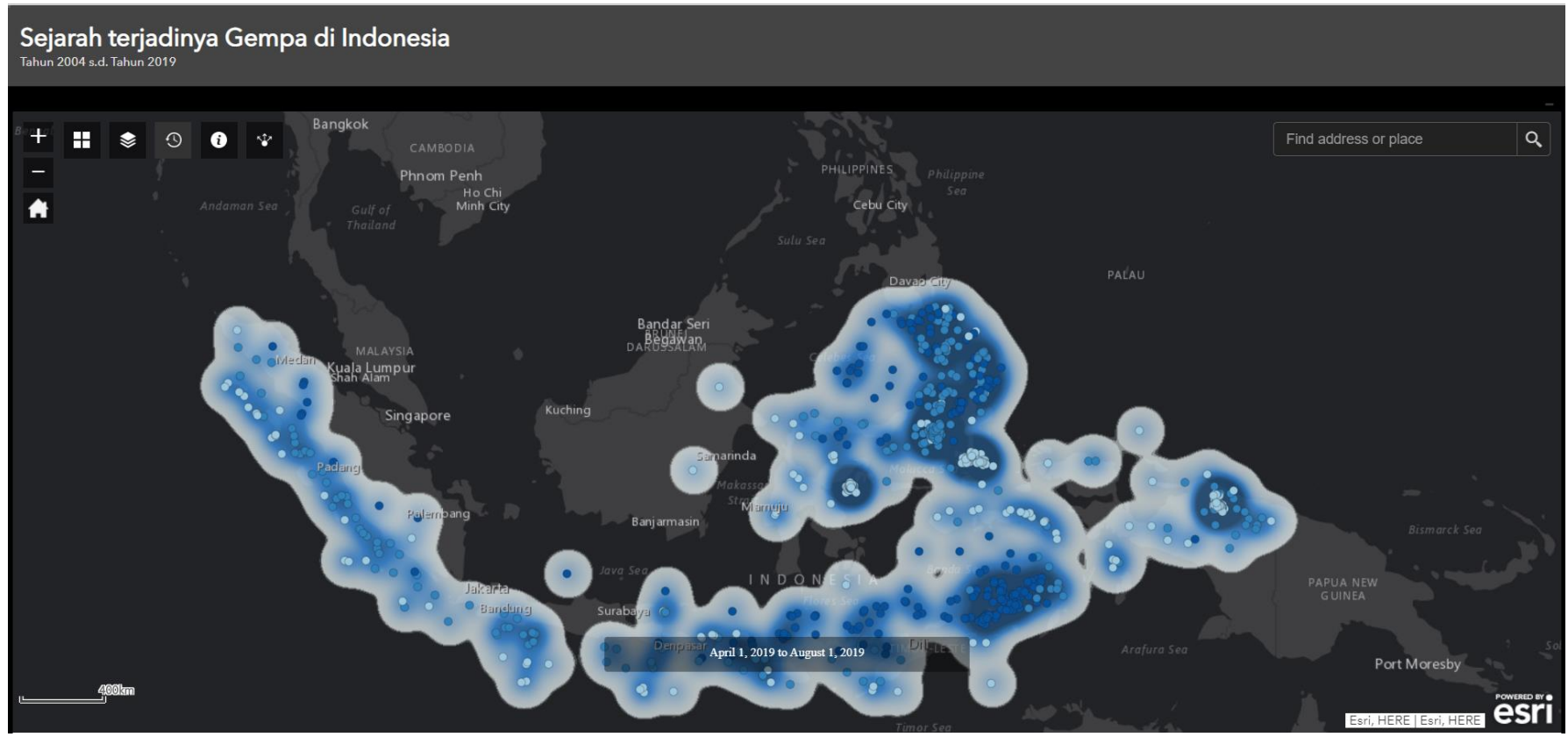

Gambar 3.7 Tampilan dashboard pada kueri kedua dari pengguna 


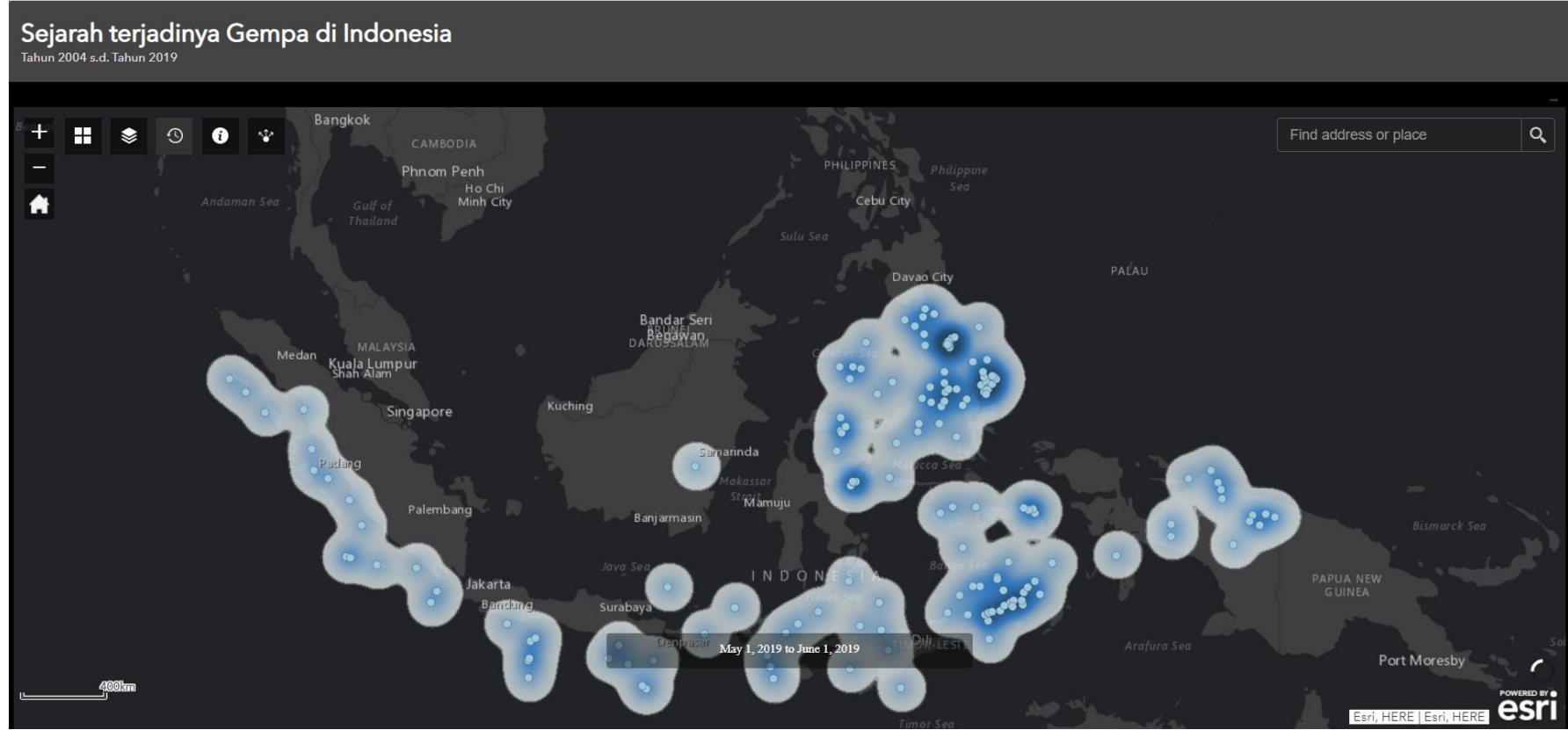

Gambar 3.8 Tampilan dashboard pada kueri ketiga dari pengguna

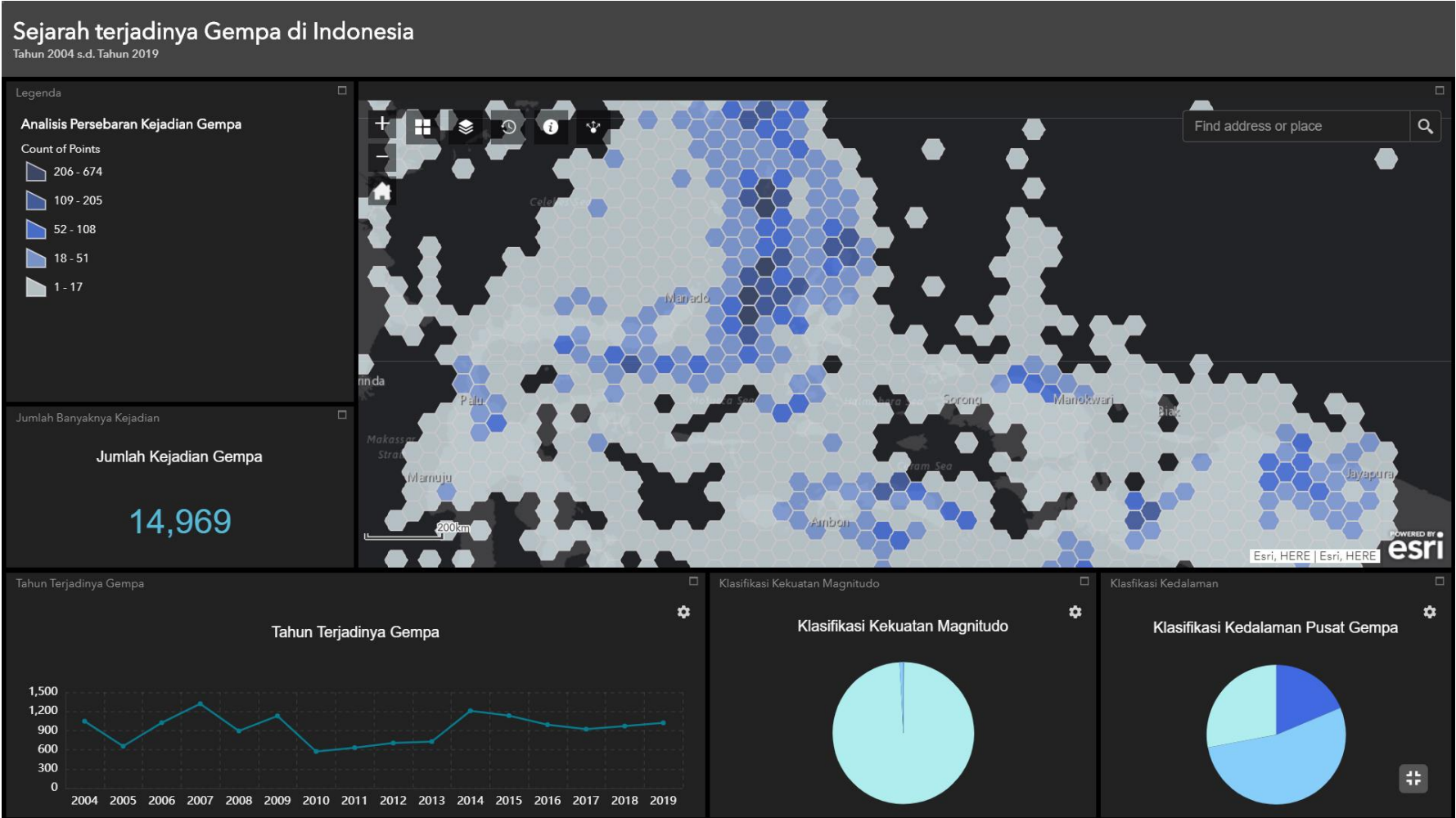

Gambar 3.9 Tampilan dashboard pada kueri keempat dari pengguna 


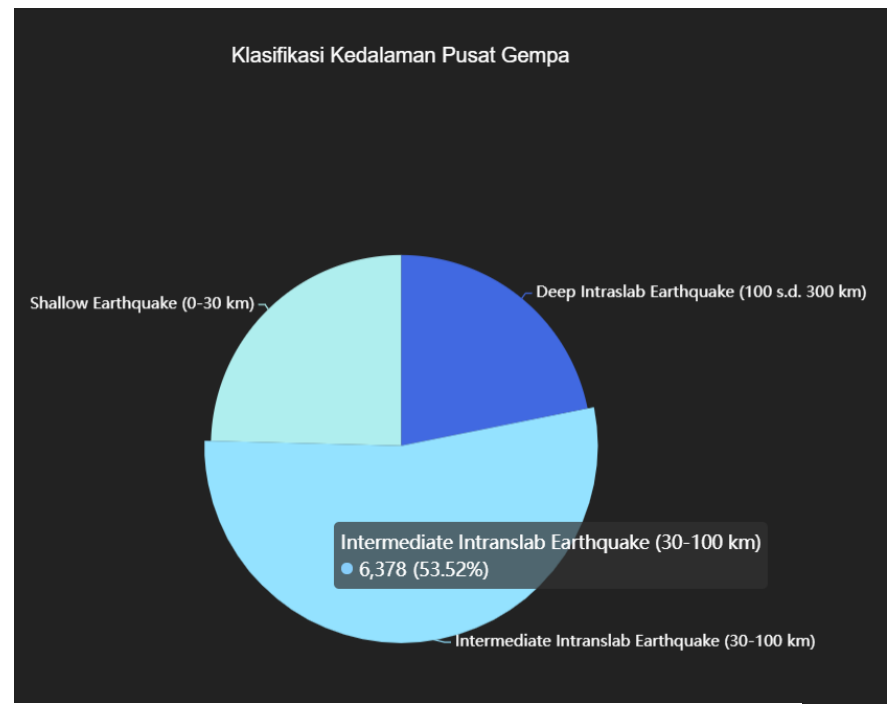

Gambar 3.10 Tampilan grafik kedalaman pusat gempa

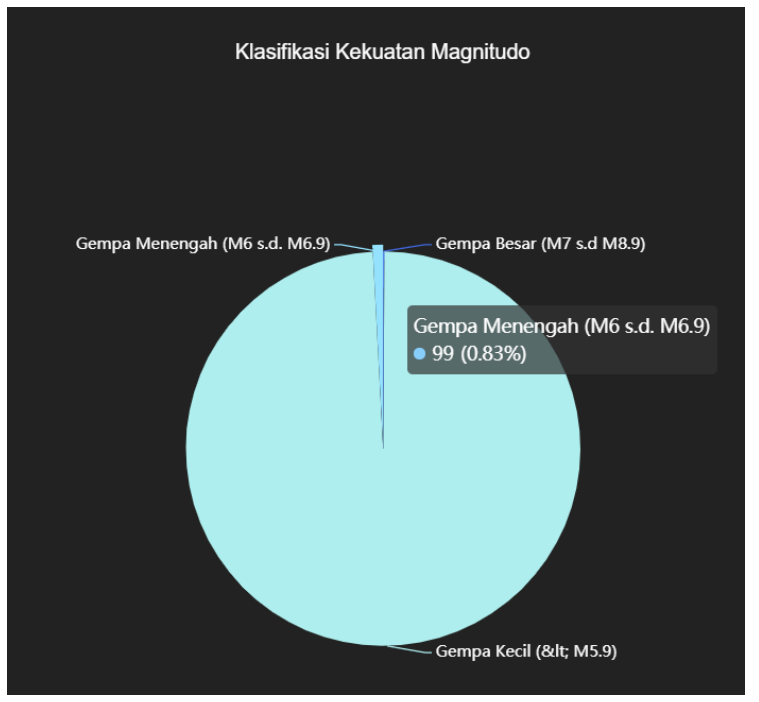

Gambar 3.11 Tampilan grafik kekuatan pusat gempa

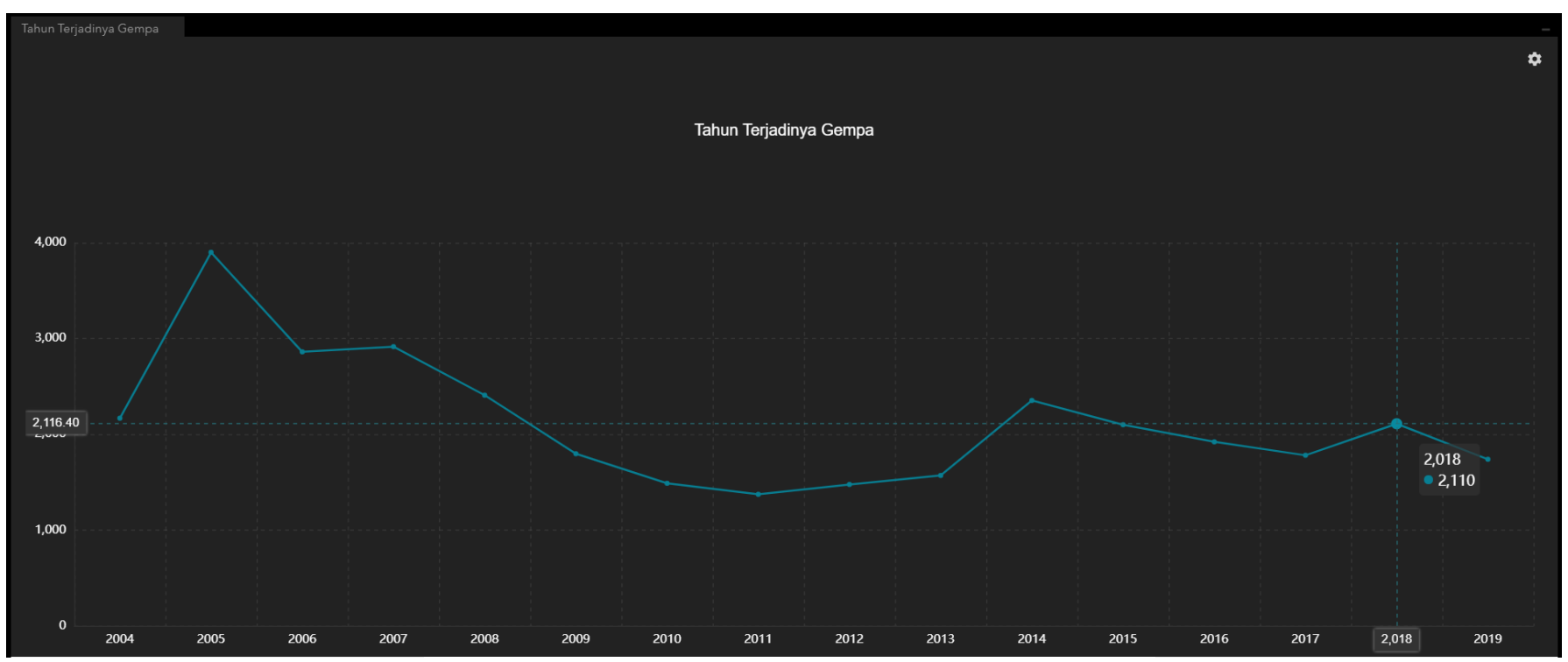

Gambar 3.12 Tampilan grafik kejadian gempa tiap tahun

\section{Pernyataan Konflik Kepentingan}

Penulis menyatakan tidak ada konflik kepentingan dalam artikel ini (The authors declare no competing interest).

\section{Referensi}

Andrienko, G., Andrienko, N., Demsar, U., Dransch, D., Dykes, J., Fabrikant, S.I., Jern, M., Kraak, M.-J., Schumann, H., Tominski, C., 2010. Space, Time and Visual Analytics. International Journal of Geographical Information Science 24, 1577-1600. doi:10.1080/13658816.2010.508043

Andrienko, N. and Andrienko, G., 2013. A visual analytics framework for spatio-temporal analysis and modelling. Data Mining and Knowledge Discovery, 27(1), pp.55-83.Bock, Y. (2003). Crustal motion in Indonesia from Global Positioning System measurements. Journal of Geophysical Research,
108(B8),

https://doi.org/10.1029/2001JB000324

Dharmawan, R.D., Suharyadi and Farda, N.M., 2017, November. Geovisualization using hexagonal tessellation for spatiotemporal earthquake data analysis in Indonesia. In International Conference on Soft Computing in Data Science (pp. 177-187). Springer, Singapore.

Hamilton, W. (1979). Tectonics of the Indonesian Region. Geological Society of Malaysia, Bulletin, 6, 3-10. https://doi.org/10.1016/0003-6870(73)90259-7

Heer, J., Mackinlay, J., Stolte, C. and Agrawala, M., 2008. Graphical histories for visualization: Supporting analysis, communication, and evaluation. IEEE transactions on visualization and computer graphics, 14(6), pp.1189-1196.

Hernández-Castro, F. and Monge-Fallas, J., 2019. Plinius: A Visualization System of Costa Rica's Tectonic Plates. Scientific Visualization, 11(2).

Ismailova, R., 2017. Web site accessibility, usability and security: a survey of government web sites in 
Kyrgyz Republic. Universal Access in the Information Society, 16(1), pp.257-264.

Jern, M. and Franzen, J., 2006, July. "GeoAnalytics"Exploring spatio-temporal and multivariate data. In Tenth International Conference on Information Visualisation (IV'06) (pp. 25-31). IEEE.

Keim, D., Andrienko, G., Fekete, J.-D., Görg, C., Kohlhammer, J., Melançon, G., 2008. Visual analytics: Definition, process, and challenges, in: Information Visualization. Springer, pp. 154-175.

Maciejewski, R., Rudolph, S., Hafen, R., Abusalah, A., Yakout M., Ouzzani, M., Cleveland, W.S., Grannis, S.J. and Ebert, D.S., 2009. A visual analytics approach to understanding spatiotemporal hotspots. IEEE Transactions on Visualization and Computer Graphics, 16(2), pp.205-220.

Meilano, I., Abidin, H. Z., Andreas, H., Gumilar, I., Sarsito, D., Rahma, H., ... Fukuda. (2012). Slip rate estimation of the lembang fault west java from geodetic observation. Journal of Disaster Research. https://doi.org/10.20965/jdr.2012.p0012

Metsalu, T. and Vilo, J., 2015. ClustVis: a web tool for visualizing clustering of multivariate data using
Principal Component Analysis and heatmap. Nucleic acids research, 43(W1), pp.W566-W570.

Popelka, S., Herman, L., Řezník, T., Pařilová, M., Jedlička, K., Bouchal, J., Kepka, M. and Charvát, K., 2019. User evaluation of map-based visual analytic tools. ISPRS International Journal of Geo-Information, 8(8), p.363.

Pusat Studi Gempa Nasional. (2017). Peta Sumber dan Bahaya Gempa Indonesia Tahun 2017. Bandung: Pusat Penelitian dan Pengembangan Perumahan dan Pemukiman.

Simons, W. J. F., Socquet, A., Vigny, C., Ambrosius, B. A. C., Abu, S. H., Promthong, C., ... Spakman, W. (2007). A decade of GPS in Southeast Asia: Resolving Sundaland motion and boundaries. Journal of Geophysical Research: Solid Earth, 112(6). https://doi.org/10.1029/2005JB003868

Von Landesberger, T., Bremm, S., Andrienko, N., Andrienko, G. and Tekušová, M., 2012, October. Visual analytics methods for categoric spatio-temporal data. In 2012 IEEE Conference on Visual Analytics Science and Technology (VAST) (pp. 183-192). IEEE. 